эксперта специалист сам не ищет доказательств, а лишь помогает делать это следователю, устанавливающему фактические данные, имеющие значение для дела. Участие специалиста- бухгалтера в перечисленных ранее следственных действиях может иметь большая значение по делам, связанным с исследованием документов бухгалтерского учета, счетных регионов.

\title{
Панасейкина В.С. \\ Опыт развития системы особо охраняемых природных территорий в России и Монголии
}

Кубанский государственный университет (Россия, Краснодар)

doi: $10.18411 / l j-31-10-2017-25$

idsp: 000001:lj-31-10-2017-25

\section{Аннотация}

В данной статье рассматриваются основные проблемы и направления развития системы особо охраняемых природных территорий России и Монголии. Перспективным направлением является дальнейшее развитие познавательного и экологического туризма на территории особо охраняемых природных территориях.

Ключевые слова: природопользование, рекреация, международное сотрудничество, экологический туризм.

Особо охраняемые природные территории во всем мире самым широким образом используются для организации экологического туризма. При этом преследуется цель обеспечение активного отдыха населения в природных условиях и воспитание адекватного восприятия природной среды, а также сбор доступной экологической и природоохранной информации во время пребывания на ООПТ.

Исторически основой территориальной охраны природы в России являются государственные природные заповедники. Система государственных заповедников как эталонов ненарушенных природных территорий - предмет заслуженной гордости России. Первый общегосударственный российский заповедник - Баргузинский - был создан на Байкале еще 11 января 1917 г. Система российских национальных парков начала формироваться в 1983 г. с создания парков «Сочинский» и «Лосиный остров».

В 1992 г. Указом Президента России было предусмотрено расширение совокупной площади государственных природных заповедников и национальных парков до 3 \% площади Российской Федерации. За 11 лет общая площадь территорий государственных природных заповедников, национальных парков, государственных природных заказников и памятников природы федерального значения была увеличена на $72 \%$.

В Списке всемирного наследия ЮНЕСКО Россия представлена 8 природными объектами, включающими 28 российских ООПТ, в числе которых 19 ООПТ федерального значения и 9 - регионального. Международный статус биосферных резерватов ЮНЕСКО имеют 28 российских заповедников и 6 национальных парков, дипломы Совета Европы - 4 заповедника (Окский, Тебердинский, ЦентральноЧерноземный и Костомукшский) [1].

За последние годы проведена значительная работа в сфере развития познавательного туризма на особо охраняемых природных территориях. На сегодняшний день 67 российских ООПТ заключили договора и соглашения с туроператорами и турагентами о предоставлении туристских услуг.

Вопросы развития познавательного туризма на особо охраняемых природных территориях получили необходимую концептуальную и правовую основу, в том числе 
путем внесения соответствующих изменений и дополнений в законодательство Российской Федерации об особо охраняемых природных территориях.

Развивалась современная инфраструктура познавательного туризма на базе федеральных государственных бюджетных учреждений, осуществляющих управление особо охраняемыми природными территориями, включая [2]:

- создание новых и модернизацию существующих музеев, визит-центров и иных демонстрационных объектов;

- обустройство экскурсионных экологических троп и туристских маршрутов, смотровых площадок и наблюдательных вышек;

- создание объектов гостевой инфраструктуры для размещения посетителей;

- обновление парка наземных и водных транспортных средств.

Получил дополнительное развитие морской круизный туризм в российском секторе Арктики и на Дальнем Востоке.

В настоящее время природный и культурный потенциал ООПТ позволяет увеличивать поток туристов и экскурсантов без ущерба для охраняемых природных комплексов и объектов. Первостепенной задачейсостоит развитие познавательного туризма в Российской Федерации, усовершенствование качества реализации туристских программ и проектов и создать условия для максимизации положительного социально-экономического эффекта от развития познавательного туризма на особо охраняемых природных территориях.

Для дальнейшего развития туризма на ООПТ необходимо [3]:

- разработать и внедрить программы обучения и повышения квалификации различных категорий работников ООПТ;

- расширить возможности для международного обмена опытом работников ООПТ, в том числе с проведением международных семинаров иконференций по актуальным проблемам функционирования ООПТ;

- внедрение современной системы экологического менеджмента всоответствии с международными стандартами и требованиями экологической сертификации.

Сохранение биологического и ландшафтного разнообразия - одно из важнейших направлений государственной политики Монголии. Национальной стратегией развития Монголии, сформулированной в 2008 г. в «Целях Тысячелетия», туризму отводится одна из ключевых позиций среди ведущих секторов экономики будущего.

Система ООПТ Монголии включает:

- заповедники;

- природные парки;

- природные резерваты;

- памятники природы.

В настоящее временя общее количество ООПТ достигло 65, занимаемая ими площадь - 22.5 млн га, что составляет 14.4\% территории Монголии; 12 (46.8\%) из них составляют строго охраняемые территории или заповедники (занимаемая площадь -10.5 млн га); 24 (43.4\%) - национальные парки (площадь 9.8 млн га), 20 (9.3\%) природные заказники (площадь 2.1 млн га) и $9(0.33 \%)$ - памятники природы (площадь 114 тыс. га). Спецификой данной территории является то, что в приграничных районах находятся самые крупные заповедники и национальные парки, потому что эти территории отличаются малонаселенностью, слабым хозяйственным освоением, а значит, преобладанием мало нарушенных природных комплексов, имеющих особую ценность для заповедования [4].

Благоприятным фактором для развития экологического туризма в Монголии можно считать симметричные процессы, происходящие в России: концепцией развития системы ООПТ федерального значения на период до 2020 г. (утв. распоряжением Правительства РФ №2322-p от 22.12.2011) предусматривается создание 
трансграничных ООПТ. Среди них две - на сопредельных территориях Монголии и России в пределах бассейна оз.Байкал: первая - в составе НП «Тункинский» (Республика Бурятия) и НП «Хубсугульский» (Монголия), вторая - в составе государственного природного биосферного заповедника «Сохондинский» (Забайкальский край) и НП «Онон-Балджинский» (Монголия).

Важным направлением дальнейшего развития сети ООПТ является создание международных трансграничных особо охраняемых природных территорий по опыту уже успешно функционирующего трехстороннего международного РоссийскоКитайско-Монгольского заповедника «Даурия».

Работа выполнена при финансовой поддержке РФФИ, проект 16-22-03001а (м).

\section{$* * *$}

1. Задевало ва С.В Про блемы и перспективы развития эко туризма на о со бо о храняемых приро дных террито риях. Вестник Бурятско го го сударственно го университета. №3. - 2012, C.154-163

2. Arumova E.S., Panaseykina V.S., Belyaeva E.A. Approaches to the management and assessment of the functioning efficiency of a regional system of protected areas // Icied-2016 international conference on innovation and entrepreneurship development: сборниктрудовконференции. Ulaanbaatar, Mongolia, 12-14 мая 2016 г.- Т. 1, Mongolian University of Science and Technology, г. Улан-батор, Монголия, 2016, C.162-164

3. БеляеваЕ.А., ПанасейкинаВ.С. Региональный механизм управления особо охраняемыми природными территориями // Wschodnioeuropejskie Czasopismo Naukowe: European Scientific Journal. [Электронныйресурс]. - Режимдоступа: http://eesa-journal.com/wp-content/uploads/2016/06/EESJ_8_1.pdf (6.12.16) - № 8., East European Scientific Journal, Warsaw, Польша, 2016, С. 29-33 Тираж: 1000

4. Оюунгэрэл Б., Неронов В.М, Лущекина А.А Трансграничное сотрудничество России и Монголии: Охраняемые природные территории и экотуризм. Пространство и время №2. 2011. С.147-152

\section{Подопригора Ю.В., Концевая А.С. \\ Стратегия социально-экономического развития как механизм повышения конкурентоспособности муниципального образования}

Томский государственный архитектурно-строительный университет (Россия, Томск)

doi: $10.18411 / l j-31-10-2017-26$

idsp: 000001:lj-31-10-2017-26

Эффективное пространственное развитие региона выступает важным условием роста конкурентоспособности муниципальных образований. Конкурентоспособность муниципального образования определяется, прежде всего, его ролью и местом в экономическом пространстве региона [1]. В настоящее время особо остро стоит задача обеспечения конкурентоспособности муниципальных образований, что является ключевым условием их устойчивого функционирования.

В основе категории «конкурентоспособность» авторы выделяют такие критерии как способность достижения высокого уровня жизни населения, более высокого валового муниципального продукта на душу населения и реализации экономического потенциала региона, способность производить конкурентоспособные товары и услуги.

В ряде муниципальных образований стратегическое планирование не достаточно эффективно выстроено. Можно выделить следующие проблемы стратегического планирования муниципальных образований России, среди которых:

- отсутствие стратегии социально-экономического развития ряда муниципальных образований; 